\title{
GB 04
}

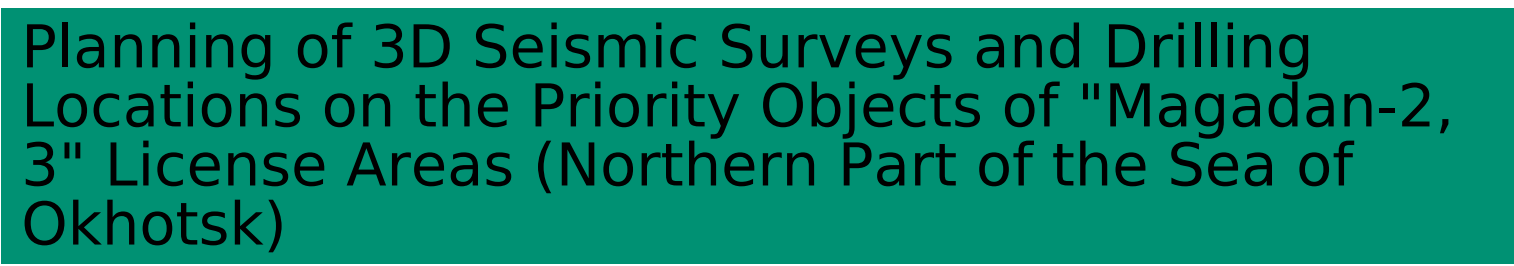

M.V. Romashov* (SakhalinNIPImorneft-RN), A.V. Kharakhinov

(SakhalinNIPImorneft-RN), E.V. Stepanova (SakhalinNIPImorneft-RN) \& O. S. Vinnikovskaya (SakhalinNIPImorneft-RN)

\section{SUMMARY}

In this report the generalization of available geological and geophysical information for licence areas of the Magadan shelf of the Okhotsk Sea was made. Showing subtotals integrated interpretation of 2D seismic data, including the received in 2013 data. The evaluation of the hydrocarbon potential of a probabilistic manner and assessment of geological risks for exploration works were made for the northern part of the Sea of Okhotsk. The most promising objects for the 3D seismic surveys were selected within the "Magadan-3" license area. Goals and objectives of the exploration works for the period up to 2019 were set. Locations for the exploration drilling were selected. Reserves growth was analyzed for the case of successful drilling 
Проект заложения 3D сетки и выбор точек бурения на первоочередных объектах ЛУ «Магадан - 2, 3» (северный сектор Охотского моря)

М.В. Ромашов* (ЗАО «РН-Шельф-Дальний Восток»), А.В. Харахинов (ЗАО «РН-ШельфДальний Восток»), Е.В. Степанова (ЗАО «РН-Шельф-Дальний Восток»), О.С. Винниковская (ЗАО «РН-Шельф-Дальний Восток»)

\section{Введение}

В рамках доклада проведено обобщение имеющейся геолого-геофизической информации на участках Магаданского шельфа Охотского моря. Показаны промежуточные итоги комплексной интерпретации материалов сейсморазведки 2D, с учётом полученных в 2013 г. данных.

Проведена оценка углеводородного потенциала участков вероятностным методом, оценены геологические риски ведения работ в северном секторе Охотского моря. Выявлены наиболее перспективные объекты для постановки сейсморазведочных работ $3 \mathrm{D}$ в пределах лицензионного участка Магадан-3.

Поставлены цели и задачи геологоразведочных работ на период до 2019 г. Выбраны точки заложения поисково-оценочных скважин, оценён прирост запасов в случае успешности бурения.

\section{Краткий обзор лицензионных участков}

Участки расположены в северной части акватории Охотского моря (рисунок 1). Экономическая освоенность прилегающей суши крайне низкая.

Важнейшими населёнными пунктами являются город Магадан, посёлки Армань и Ола. В областном центре находятся международный аэропорт и крупный морской порт, расположенные в бухте Нагаева.

Глубины моря в пределах участков изменяются от 50 до 300 метров. Средние даты появленияисчезновения тяжелого льда: 1 декада февраля - 3 декада мая. Среднее число штормов: от 6-9 до 18-24 за месяц (январь-декабрь) со скоростью ветра 30-40 м/с, волнением 9-10 баллов.

Сейсмическая обстановка: 8 баллов - 1 раз в 1000 лет [1].

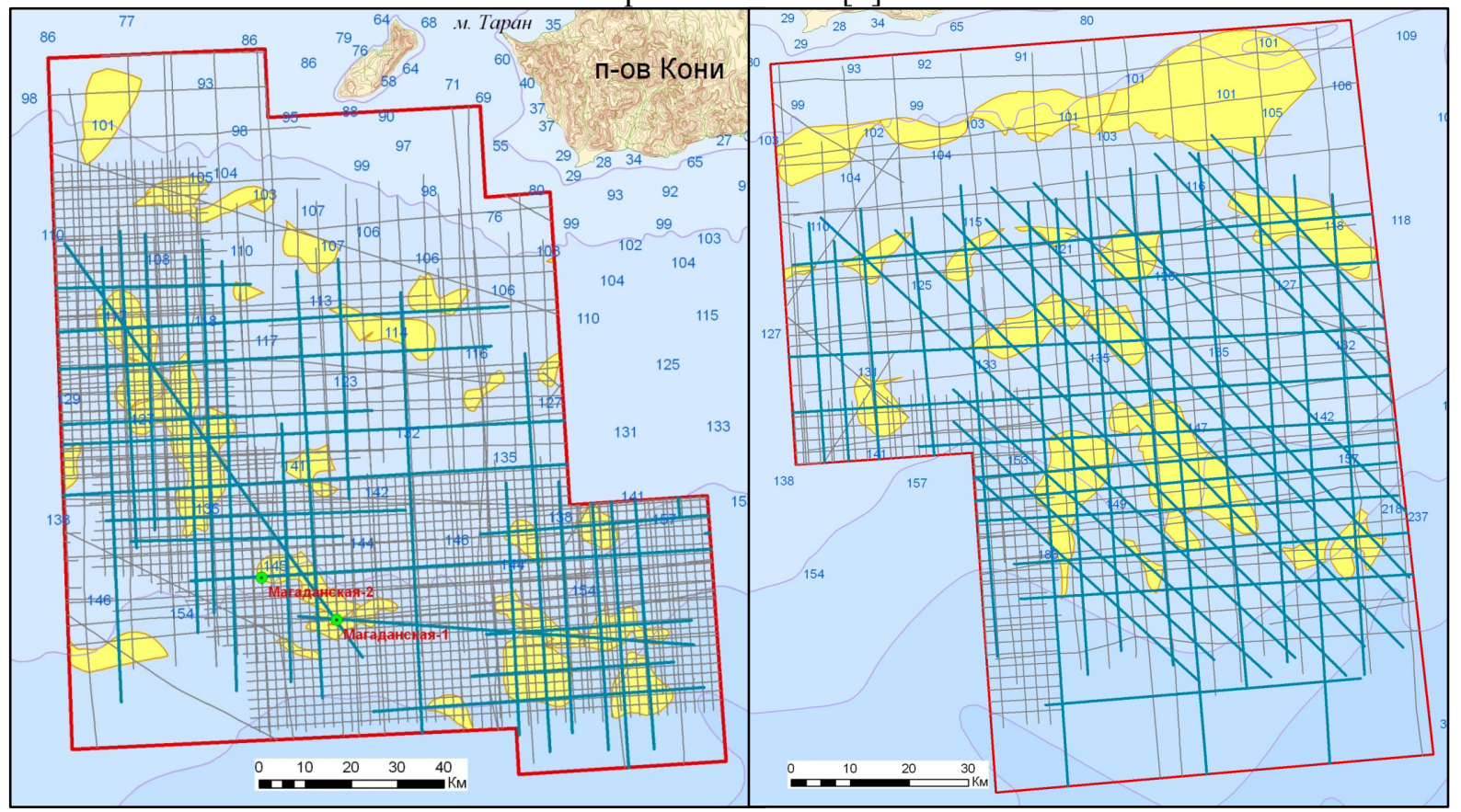

a) участок Магадан-2

б) участок Магадан-3

Рисунок 1 Схема расположения лицензионных участков северного сектора Охотского моря

Углеводородный потенциал Дальнего Востока 2014

Г. Южно-Сахалинск, 7-9 октября 2014 г. 
Изученность материалами сейсморазведки 2D варьируется от 0,726 пог. км/км ${ }^{2}$ на участке Магадан-3 до 1,05 пог. км/км² на участке Магадан-2.

В пределах участка Магадан-2 пробурены две скважины (Магаданская-1, 2), одна из которых вскрыла наиболее перспективный синрифтовый комплекс. На сопредельном участке Магадан-1 пробурена скважина Хмитевская-2, вскрывшая только пострифтовые отложения.

\section{Оценка углеводородного потенциала, бассейновый анализ, планирование ГРР}

В рамках работ по геолого-геофизическому изучению северного сектора Охотского моря, с целью открытия залежей углеводородов, были оценены перспективы участков на основе имеющихся, а также полученных в последние годы данных геофизических методов исследования, оценены геологические риски.

Наиболее перспективным с точки зрения поисков залежей нефти и газа является синрифтовый комплекс. Ловушки прогнозируются как в антиклинальных поднятиях, так и в зонах выклинивания отложений комплекса. Региональным флюидоупором могут служить пострифтовые глинистые и глинисто-кремнистые отложения [1].

Для подготовки выявленных структур к поисково-оценочному бурению планируются следующие объёмы работ:

1. проведение электроразведочных работ объёмом: 300 пог. км (Нагаевская структура, ЛУ Магадан-2), 400 пог. км (Умарская структура, ЛУ Магадан-3);

2. выполнение геохимической съёмки в объёмах: по 100 донных проб на каждом участке, а также съёмка с применением буксируемого масс-спектрометра;

3. сейсморазведочные работы 3D площадью $1200 \mathrm{kм}^{2}$ в пределах лицензионного участка Магадан-3 (Умарская структура);

4. подготовка к проведению инженерно-геологических изысканий и выбор площадок для поисково-оценочного бурения;

5. проведение работ по экологическому мониторингу окружающей среды.

Выполнение перечисленных видов работ поможет решить следующий круг задач:

1. уточнить контуры структур и внутреннее строение синрифтового комплекса;

2. уточнить положение поверхности фундамента, что позволит более качественно выполнить бассейновое моделирование и оценить элементы нефтегазоносных систем;

3. на основании динамического и AVO анализов сделать прогноз коллекторов, так как основные риски на участках, связаны с их наличием и распространением;

4. на основании данных геохимической съёмки выделить зоны повышенного содержания органического вещества в придонных осадках, оценить связь таких аномальных зон с возможным существованием залежей;

5. на основании данных электроразведки получить дополнительную информацию о строении перспективных структур и электромагнитных свойствах среды;

6. избежать заложения точек бурения в неоптимальных геологических условиях;

7. снизить риски проектирования инженерных площадок под бурение в местах скопления мелкого газа, а также экологические риски.

\section{Выводы}

В случае успеха поисково-оценочного бурения на лицензионных участках Магаданского шельфа Охотского моря, прирост ресурсной базы может составить: 62,9 млн. тонн нефти, 46,2 млн. тонн конденсата и 308,1 млрд. м³ газа. Разработка этих ресурсов может послужить существенным стимулом для развития инфраструктуры региона.

\section{Библиография}

1. Петровская, Н.А., Грецкая, Е.В., Спирина, Е.Е., Савишкина, М.А [2010] Геологическое строение и углеводородный потенциал седиментационных бассейнов Магаданского шельфа Отчёт OAO «Дальморнефтегеофизика», г. Южно-Сахалинск, 1-207. 